\title{
KEBIJAKAN KRIMINAL DALAM PENCEGAHAN DAN PENANGGULANGAN NARKOTIKA DI KOTA PALEMBANG
}

\author{
Oleh : \\ Ruben Achmad* \\ Neisa Angrum Adisti *
}

\begin{abstract}
ABSTRAK
Tujuan penulisan penelitian ini adalah untuk menganalisis kebijakan kriminal dalam pencegahan dan penindakan kejahatan narkotika di Indonesia dan kebijakan kriminal dalam pencegahan dan penindakan kejahatan narkotika khususnya di Kota Palembang. Kebijakan kiminal pencegahan dan penanggulangan narkotika di Indonesia dilakukan dengan 2 (dua) cara yaitu kebijakan Penal dan Non penal. Temuan dari analisis hasil penelitian aspek penal terhadap narkotika dan psikotropika, merupakan bahan masukan untuk melakukan perbaikan dalam perencanaan penanggulangan penyalahgunaan narkotika dikemudian hari.mSelain dengan peraturan perundangundangan upaya penanggulangan dan pecegahan Narkotika dilakukan secara sinergi beberapa lembaga yang terkait satu sama lain ,P4GN adalah Pemberantasan Peredaran Gelap Narkoba dan Perkusor yang merupakan suatu program penanggulangan pencegahan narkotika. Pencegahan Pemberantasan Penyalahgunaan dan Peredaran Gelap Narkoba (P4GN) adalah upaya sistematis berdasarkan data penyalahgunaan narkoba yang tepat dan akurat, perencanaan yang efektif dan efisien dalam rangka mencegah, melindungi dan menyelamatkan warga negara dari ancaman bahaya penyalahgunaan narkoba untuk itu diperlukan kepedulian dari seluruh instansi pemerintah dalam upaya tersebut dengan mendorong satgas di instansi pemerintah menjadi pelaku P4GN secara mandiri. Upaya yang paling tepat dalam pencegahan dan penyalahgunaan narkotika adalah upaya demand yang menitik beratkan pada perbaikan pelaku yaitu penyuluhan dan juga rehabilitasi. Dibandingkan penjara , rehabilitasi lebih tepat dilaksanakan bagi pengguna narkotika. Dikarenakan efek negatif penjara yang belum tentu memperbaiki keadaan pelaku . Namun pada kenyataannya, hakim sangat jarang memutus dengan putusan rehabilitasi
\end{abstract}

Kata Kunci: Kebijakan Kriminal, Narkotika, Kota Palembang

\section{A. Latar Belakang}

Indonesia hampir 15 tahun reformasi telah dijalani oleh bangsa Indonesia berbagai upaya perubahan terus dilakukan baik dalam kebijakan ekonomi, politik, sosial, budaya dan juga reformasi di bidang hukum namun masih saja tujuan reformasi belum mampu terwujud. Dari sekian agenda reformasi yang paling menyedihkan adalah kegagalan di bidang reformasi hukum khususnya dalam penegakan hukum di negeri ini.

Tingkat kepercayaan masyarakat terhadap penegakan hukum di negri ini dari hari ke hari grafiknya terus mengalami penurunan. Tingkat ketidak puasan masyarakat terhadap penegakan hukum di negri ini semakin meningkat, hal ini dapat terlihat dengan jelas dari hasil

\footnotetext{
* Pengajar Fakultas Hukum UNSRI

* Pengajar Fakultas Hukum UNSRI
} 
survei yang dilakukan Lembaga Survei Indonesia ${ }^{1}$ yang menempatkan tingkat ketidak percayaan publik terhadap penegakan hukum saat ini berada pada angka 56 persen dan hanya 29,8 persen yang menyatakan puas, jika dibandingkan dengan pemerintahan sebelumnya hanya 22,6 persen yang mengatakan penegakan hukum di era pemerintahan sekarang ini lebih baik dari pemerintahan sebelumnya.

Tugas pokok dan fungsi Polri, selain sebagai pengayom masyarakat juga sebagai penegak hukum. Fungsi tersebut merupakan sebagian dari implementasi Pasal 1 ayat (5) UU Nomor 2 Tahun 2002 tentang Kepolisian Negara Republik Indonesia menetapkan bahwa:

Keamanan dan ketertiban masyarakat adalah suatu kondisi dinamis masyarakat sebagai salah satu prasyarat terselenggaranya proses pembangunan nasional yang ditandai oleh terjaminnya tertib dan tegaknya hukum serta terbinanya ketentraman yang mengandung kemampuan membina serta mengembangkan potensi dan kekuatan masyarakat dalam menangkal, mencegah, dan menanggulangi segala bentuk pelanggaran hukum dan bentuk- bentuk gangguan lainnya dapat meresahkan masyarakat.

Sejalan dengan hal tersebut, Soerjono Soekanto² berpendapat bahwa: "hukum dan penegak hukum merupakan sebagian faktor penegakan hukum yang tidak bisa diabaikan, jika diabaikan akan menyebabkan tidak tercapainya penegakan hukum yang diharapkan". Penegakan hukum, penjagaan keamanan dan ketertiban masyarakat (Kamtibmas) serta pelayanan dan pengayoman masyarakat adalah tugas pokok polisi sebagai profesi mulia, yang aplikasinya harus berdasarkan undang-undang yang berlaku dan hak azasi manusia. Atau dengan kata lain harus bertindak secara professional dan memegang kode etik secara ketat dan keras, sehingga tidak terjerumus kedalam prilaku yang dibenci masyarakat .

Masyarakat dan polisi merupakan dua kegiatan yang tidak bisa di pisahkan. Tanpa masyarakat, tidak akan ada polisi dan tanpa polisi, proses-proses dalam masyarakat tidak akan berjalan dengan lancar dan produktif. Kenyataan tersebut di atas, menurut Barda Nawawi Arief $^{3}$, bahwa Polri dalam menjalankan tugasnya berperan ganda baik sebagai penegak

\footnotetext{
${ }^{1}$ LSI tangkap ketidak puasan rakyat atas penegak hokum: “Sindonews.com Senin 8April 2019 00:32". Menurut Dewi survey dilakukan 1 s/d 4 April 2019

${ }^{2}$ Soerjono Soekanto, Faktor-faktor yang Mempengaruhi Penegakan Hukum, Cet Kelima, Rajawali, Jakarta, 2004, hal., 5.

${ }^{3}$ Barda Nawawi, Bunga Rampai Kebijakan Hukum Pidana, PT. Citra Aditya Bakti, Bandung, 2005, hal., 5.
} 
hukum maupun sebagai pekerja sosial (sosial worker) pada aspek sosial dan kemasyarakatan (pelayanan dan pengabdian). Prilaku masyarakat dan penegak hukum menurut Soerjono Soekanto ${ }^{4}$ berpendapat bahwa :

Salah satu fungsi hukum baik sebagai kaidah maupun sebagai sikap tindak atau perilaku teratur adalah membimbing perilaku manusia. Masalah pengaruh hukum tidak hanya terbatas pada timbulnya ketaatan atau kepatuhan pada hukum, tapi mencakup efek total dari hukum terhadap sikap tindak atau prilaku baik yang bersifat positif maupun negatif.

Pembaharuan Undang-undang Kepolisian Indonesia, UU No. 2 Tahun 2002 dimaksudkan untuk lebih memantapkan kedudukan dan peran Polri sebagai fungsi pemerintahan meliputi pemeliharaan keamanan dan ketertiban masyarakat, penegakan hukum, perlindungan dan pengayoman dan pelayanan kepada masyarakat yang menjunjung tinggi hak asasi manusia, harus bebas dari pengaruh kekuasaan pihak manapun, yakni yang dilaksanakan secara merdeka terlepas dari pengaruh kekuasaan pemerintah dan pengaruh kekuasaan lainnya.

Dalam kurun waktu 3 tahun terakhir prosentase tingkat ketidak puasan masyarakat terhadap penegakan hukum di negri ini terus mengalami kenaikan yang cukup signifikan Januari 2015, 37,4 persen, Oktober 2016 41,2, September 2017, 50,3 persen, Oktober 2018, 50,3 dan yang terakhir April 2019, sungguh mengejutkan mencapai 56,0 persen. Dan yang paling mencengangkan ternyata masyarakat di desa justru tingkat ketidakpuasannya mencapai pada angka 61,1 persen sementara di kota mencapai 48,6 persen.

Namun ditengah persepsi minim terhadap kinerja Polri, "masih ada harapan public" terhadap garda depan keamanan rakya tersebut. Sebagian public masih menilai positif kinerja Polri dalam mewujudkan brata ketiga dalam kapasitas sebagai pengayom, pelindung, dan pelayan masyarakat. ${ }^{5}$ Hal itu digambarkan:

\footnotetext{
${ }^{4}$ Soerjono Soekanto, Efektivitas Hukum Dan Peranan Sanksi, Remaja Karya, Bandung, 2005, hal 10.

${ }^{5}$ KOMPAS, Senin, 13 April 2019, "Politik \& Jukum" hal. 5
} 


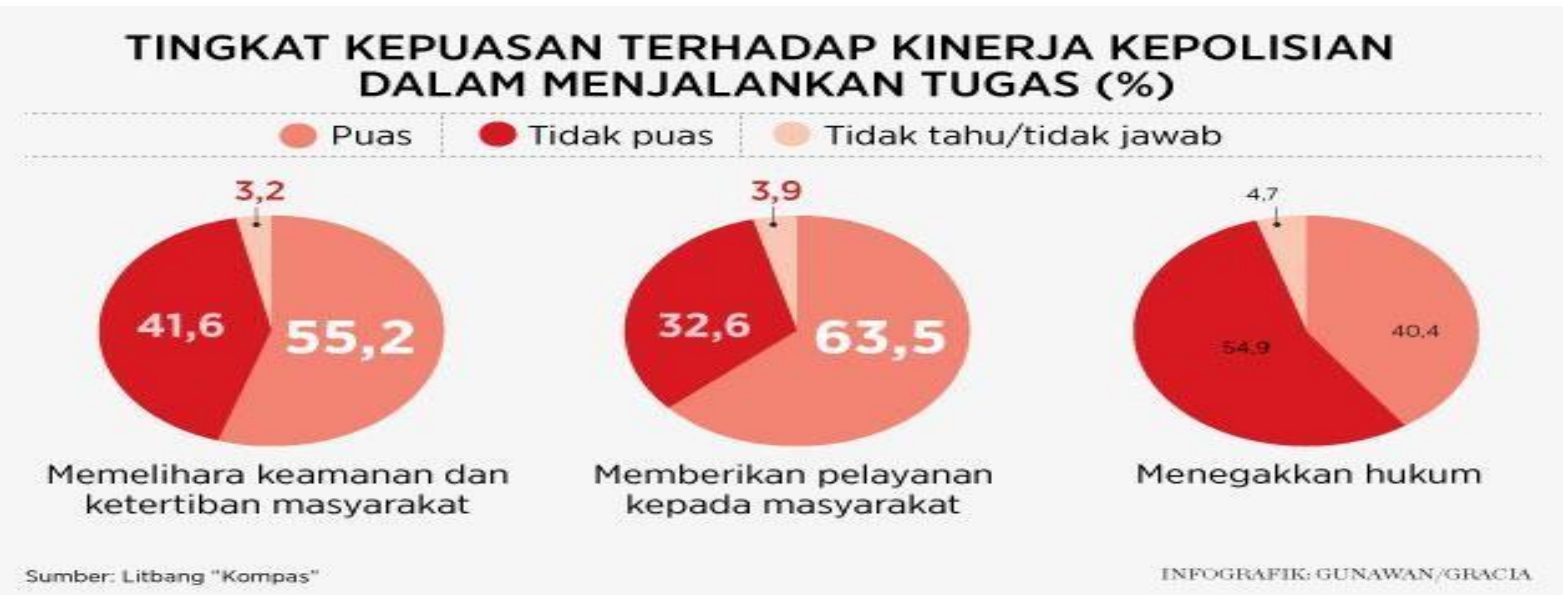

Berdasarkan latar belakang di atas, maka perlu dilakukan penelitian tentang bagaimana tugas dan fungsi penegak hukum, yaitu kepolisian untuk meningkatkan kepercayaan publik terhadap penegak hukum

\section{B. Rumusan Masalah}

Sehubungan dengan uraian di atas, penelitian yang berjudul Kebijakan Kriminal Terhadap Penyalahgunaan Narkotika di Kota Palembang ini akan menjawab permasalahan pokok, yakni:

a. Bagaimana kebijakan kriminal dalam pencegahan dan penindakan kejahatan narkotika di Indonesia?

b. Bagaimana kebijakan kriminal dalam pencegahan dan penindakan kejahatan narkotika khususnya di Kota Palembang?

\section{Pembahasan}

\section{Kebijakan Kriminal Dalam Pencegahan Dan Penindakan Kejahatan Narkotika Di} Indonesia

Secara teoritis kebijakan krimiminalisasi terhadap penyalahgunaan narkotika berangkat dari pemikiran yang dikemukakan oleh Peter Hoefnagels bahwasanya:

Teori G. Peter Hoefnagels yang menyatakan bahwa "Criminal policy is the rational organization of social reactions to crime." Teori ini merupakan perumusan kembali dari teori Marc Ancel yang menyatakan bahwa "criminal policy is the rational organization of the

\footnotetext{
${ }^{6}$ A. R. Sujono, Op. Cit., hal. 61-62.
} 
control of crime by society" (upaya rasional dari masyarakat dalam menanggulangi kejahatan $)^{7}$. Kemudian Hoefnagels merumuskan secara lebih rinci:
a. criminal policy as a science ofresponses;
b. criminal policy as a science of crimeprevention;
c. criminal policy is a policy of designating human behavior ascrime;
d. criminal policy is rational total of the responses tocrime.

Berdasarkan kerangka pemikiran teoritis diatas, maka penanggulangan terhadap penyalahgunaan narkotika akan ditempuh melalui dua aspek yakni :

1. Aspek penal (hukum pidana);

2. Aspek non penal (pencegahan).

Aspek Penal, diawali dengan analisis terhadap ketentuan perundang-undangan pidana yang berkaitan dengan narkotika dan psikotropika khususnya terhadap kebijakan hukum pidana (penal policy), melalui kajian normatif yang merupakan tahap kebijakan legislatief. Kajian selanjutnya dilakukan dengan mengamati pelaksanaan ketentuan perundang-undangan pidana (in abstrakto) narkotika dan psikotropika ke perundangundangan pidana (in konkrito) melalui mekanisme sistem peradilan pidana terpadu yang merupakan tahap kebijakan aplikatief yang selanjutnya akan diteruskan pada tahak kebijakan eksekutif. Temuan dari analisis hasil penelitian aspek penal terhadap narkotika dan psikotropika, merupakan bahan masukan untuk melakukan perbaikan dalam perencanaan penanggulangan penyalahgunaan narkotika dikemudian hari.

Kebijakan kriminal terhadap narkotika di Indonesia harus dilakukan sesuai dengan konsep-konsep dasar kriminalisasi yang telah kami uraikan di atas. Kebijakan kriminal ini harus merupakan bagian dari kebijakan sosial atau kebijakan pembangunan nasional. Penegasan bahwa antara upaya penanggulangan kejahatan dan perencanaan sosial perlu terintegrasi dalam keseluruhan kebijakan sosial sosial dan perencanaan pembangunan. Sudarto menyatakan bahwa apabila hukum pidana hendak dilibatkan dalam usaha mengatasi segi-segi negatif dari perkembangan masyarakat (modernisasi), maka hendaknya dilihat dalam hubungan keseluruhan politik kriminal atau social defence planing, dan inipun harus merupakan bagian integral dari perencanaan pembangunan nasional. ${ }^{8}$

Dalam hal penanggulangan tindak pidana narkotika yang sangat erat kaitannya dengan kebijakan sosial. Selain itu kebijakan ini juga harus disesuaikan dengan kebutuhan

\footnotetext{
${ }^{7}$ Marc Ancel, Social Defence; A Modern Approach to Criminal Problem, Routledge and Kegan Paul, London, 1965, hal. 208-209.

${ }^{8}$ Sudarto, Hukum dan Hukum Pidana, ,Bandung: Alumni, 1977, hal. 38.
} 
yang ingin dicapai dan kondisi sosial budaya Indonesia, walaupun terdapat kreteria yang diatur suatu pedoman namun tetap saja ada suatu nilai yang sesuai dengan jiwa bangsa Indonesia. Konsep hukum seperti ini sesuai dengan pendapat Gustav Karel Von Savigny yang menyatakan bahwa pada intinya hukum itu terdiri dari unsur politis (das politische element) dan unsur teknis (das technische element). Unsur politis artinya bahwa isi hukum itu adalah pencerminan jiwa bangsa maknanya ada keterkaitan yang mendalam atas isi hukum itu dengan keyakinan-keyakinan bangsa atau jiwa bangsa (volk geist), sedang unsur teknis adalah bahwa mengenai pengolahan hukum diserahkan kepada kaum juris yang merupakan para ahli dalam bidang itu. ${ }^{9}$

Perkembangan pengaturan melalui instrumen hukum terhadap keberadaan narkotika merupakan suatu siklus yang tidak terpisahkan dengan dinamika perkembangan sosial masyarakat dalam menyikapi keberadaan narkotika di Indonesia.

Masalah narkotika telah menjadi masalah dunia. Hal ini terbukti dengan usaha dari masing-masing negara secara internal untuk menanggulangi bahaya narkotika antara lain dalam bentuk konvensi-konvensi internasional, yang paling akhir melalui konvensi PBB mengenai Lalu-lintas Perdagangan Gelap Obat Narkotika dan Psikotropika, Tanggal 19 Desember 1988.

Dengan demikian dengan mempertimbangkan fenomena bahwa tindak pidana narkotika bukan permasalahan nasional semata, tetapi berdimensi regional maupun internasional (trans-nasional). Oleh karena itu kebijakan kriminal terhadap tindak pidana narkotika harus bersifat komprehensif dan merupakan reaksi terhadap bahaya yang ditimbulkan. Bahaya tersebut baik terhadap kehidupan sosial ekonomi maupun kehidupan politik dan keamanan yang semuanya termasuk kategori kebijakan sosial.

Kebijakan Hukum Pidana dalam Undang-Undang Republik Indonesia Nomor 35 Tahun 2009 Tentang Narkotika merupakan kebijakan penal dalam undang-undang itu antara lain dapat diidentifikasikan sebagai berikut :

1. Kebijakan kriminalisasi

- Kebijakan kriminalisasi dari Undang-Undang Narkotika terfokus pada penyalahgunaan dan peredaran "narkoba"nya (mulai dari penanaman, produksi, penyaluran, lalu lintas, pengedaran sampai ke pemakaiannya, termasuk pemakaian

9 Theo Huijbers OSC,Filsafat Hukum Dalam Lintas Sejarah, (Bandung:Penerbit Yayasan Knisius,1982),hal. 118. Jeremy Bentham menyatakan bahwa tujuan hukum itu harus berguna bagi masyarakat untuk mencapai kebahagiaan sebesar-besarnya. Ide pokok dari Bentham masyarakat harus diatur dengan baik, kalau institusi-institusi yang berkepentingan dibentuk sedemikian rupa sehingga menghasilkan kepuasan yang sebesar mungkin bagi semua orang termasuk masyarakat itu. 
pribadi), tidak pada kekayaan ("property/assets") yang diperoleh dari tindak pidana "narkoba"nya itu sendiri.

- Kebijakan kriminalisasi demikian memang sesuai dengan konvensi PBB mengenai narkotika dan Psikotropika. Namun, sebenarnya kebijakan kriminalisasi menurut konvensi PBB tidak hanya itu, Khususnya untuk narkotika. Konvensi PBB juga menyatakan agar dijadikan/ditetapkan sebagai suatu tindak pidana, perbuatan "mengubah atau mengalihkan/menstransfer kekayaan yang diketahuinya berasal dari tindak pidana narkotika atau berasal dari keikutsertaan melakukan tindak pidana itu, untuk tujuan menyembunyikan asal usul gelap dari kekayaan itu atau untuk tujuan membantu seseorang menghindari akibat-akibat hukum dari keterlibatannya melakukan tindak pidana itu. Rumusan tindak pidana seperti di atas tidak ada dalam Undang-Undang Narkotika (Nomor 35 Tahun 2009). Namun saat ini sudah dimasukkan dalam Undang-Undang Nomor 15 Tahun 2002 tentang Tindak Pidana Pencucian Uang (Money Laundering). Hanya patut dicatat, bahwa menurut UndangUndang Nomor 15 Tahun 2002 (Pasal 2) ada pembatasan jumlah/nilai uang atau harta kekayaan yang dicuci, yaitu Rp. 500.000.000,-(lima ratus juta rupiah) atau lebih. Pembatasan ini dapat juga mempengaruhi efektivitas penegakan hukumnya karena tidak mustahil dapat digunakan sebagai celah-celah untuk lolos dari jaringan hukum dengan jalan memecah-mecah uang yang dicuci itu dibawah nilai Rp. 500.000.000,- (lima ratus juta rupiah).

2. Masalah Kualifikasi Tindak Pidana

- Undang-Undang No. 35 Tahun 2009 Tentang Narkotika sama sekali tidak menyebutkan kualifikasi Tindak Pidana.

- Tidak jelas pula alasan perubahan sikap/kebijakan pembuat Undang-Undang Nomor 35 Tahun 2009 (Narkotika) yang tidak menyebutkan kualifikasi delik, pada hal dalam Undang-Undang Narkotika yang lama (Undang-Undang Nomor 9 Tahun 1976) disebutkan kualifikasinya secara tegas dalam Pasal 50, yaitu semua delik dinyatakan sebagai "kejahatan" kecuali 1 (satu) tindak pidana (dalam Pasal 47) dinyatakan sebagai "pelanggaran" yang hanya diancam dengan pidana kurungan maksimum 1 (satu) tahun. Di dalam Undang-Undang Nomor 22 Tahun 1997, ada juga tindak pidana yang diancam dengan pidana ringan berupa "kurungan" yakni Pasal 86, Pasal 88, Pasal 94, tetapi tidak dinyatakan / dikualifikasikan sebagai "pelanggaran". 
- Memperhatikan adanya sikap/kebijakan yang berbeda antara pembuat undangundang itu (yang juga terlihat di berbagai undang-undang lainnya), hendaknya pembuat undang-undang menegaskan kualifikasi yuridis dari suatu tindak pidana apakah sebagai "kejahatan" atau "pelanggaran". Tidak adanya penetapan kualifikasi yuridis dapat menimbulkan masalah yuridis dalam praktek, baik dari aspek yuridis

- materiel maupun dari aspek yuridis formal. Hal ini berarti dapat mempengaruhi efektivitas penegakan hukumnya.

\section{Masalah Perumusan Sanksi Pidana}

- Kebanyakan sanksi pidana dalam kedua Undang-Undang Narkotika di atas dirumuskan secara kumulatif. Bahkan, ada pidana penjara seumur hidup yang dikumulasikan dengan pidana denda. Hal ini dapat menimbulkan masalah karena dengan perumusan kumulatif yang bersifat "mengharuskan" (imperatif) itu, seseorang yang dijatuhi pidana penjara seumur hidup seolah-olah harus juga dijatuhi pidana denda.

- Perumusan kumulasi yang paling banyak adalah antara pidana penjara/pidana mati dan denda yang cukup besar (ratusan juta dan ada yang miliaran rupiah). Hal ini pun dikhawatirkan tidak efektif dan dapat menimbulkan masalah, karena ada ketentuan dalam Pasal 148Undang-Undang No. 35 Tahun 2009 bahwa "apabila denda tidak dibayar, dikenakan pidana penjara paling laman 2 (dua) tahun. Dengan demikian, kemungkinan besar ancaman pidana denda yang sangat besar itu tidak akan efektif, karena kalau tidak dibayar Bagi terdakwa, ancaman pidana penjara pengganti denda itu mungkin tidak mempunyai pengaruh apa-apa, karena apabila denda itu dibayar, ia pun akan tetap terkena pidana penjara (karena diancamkan secara kumulatif). Oleh karena itu, kemungkinan besar ia tidak akan membayar dendanya.

- Demikian pula pidana denda yang tinggi itu tidak akan efektif dikenakan kepada korporasi, karena dalam Undang-Undang Narkotika ini tidak ada aturan khusus bagi korporasi yang tidak membayar denda.

- $\quad$ Aturan umum dalam Pasal 30 KUHP di atas, ditujukan kepada subyek hukum berupa "orang" bukan ditujukan kepada "korporasi"

- $\quad$ Disamping itu, patut dicatat, bahwa di dalam Undang-Undang No 35 Tahun 2009 tentang Narkotika ini mengatur secara khusus sanksi pidana yang dapat dijatuhkan terhadap korporasi. 


\section{Masalah Ancaman Pidana Minimal}

- Dalam Undang-Undang Narkotika ini ada delik yang diberi ancaman pidana minimal khusus. Kebijakan formulasi demikian merupakan penyimpangan dari sistem KUHP.

- Penyimpangan yang demikian ini seharusnya disertai dengan pedoman atau aturan penerapan pidana minimal yang bersifat khusus pula agar tidak menimbulkan masalah apabila ada penyertaan, percobaan, concursus, recidive, dan lain-lain alasan peringanan/pemberatan pidana.

- Dalam kenyataan praktek hakim mengalami kesulitan menerapkan ancaman pidana minimal ini; sehingga ada hakim yang menjatuhkan pidana dibawah ancaman minimal.

\section{Masalah Percobaan, Pembantuan dan Permufakatan Jahat}

- Menurut Undang-Undang Narkotika (Pasal 132), percobaan atau permufakatan jahat dipidana sama dengan delik yang bersangkutan.

- Jadi, "perbantuan" ("medeplichtige") dalam melakukan Tindak Pidana (TP) narkotika. Menurut Undang-Undang Narkotika "pembantu" dipidana sama dengan pelaku Tindak Pidana (TP), karena hal demikian pun ditegaskan dalam Konvensi PBB mengenai Pemberantasan Peredaran Gelap Narkotika dan Psikotropika 1988.

- Mengenai "permufakatan jahat" juga terlihat aturan yang menyatakan bahwa pelakunya dipidana dengan pidana penjara yang sama sesuai dengan ketentuan sebagaimana yang dirumuskan dalam Psal 111 s.d. Pasal 126 dan Pasal 129.

- Menurut ketentuan Pasal 132 ayat (2) dalam hal perbuatan sebagaimana dimaksud dalam Pasal 111 s.d Pasal 126 dan Pasal 129 dilakukan secara terorganisasi, pidana penjara dan pidana denda maksimumnya ditambah $1 / 3$ (sepertiga).

Dari uraian di atas, dapatlah ditegaskan aturan pemidanaan yang terdapat dalam Undang-Undang No. 35 Tahun 2009 tentang Narkotika masih terdapat beberapa kekurangan sehingga akan berpengaruh pada pengakkannya.

Dalam konvensi Psikotropika 1971 (yang sudah diratifikasi dengan Undang-Undang No. 8 Tahun 1996) maupun Konvensi Pemberantasan Peredaran Gelap Narkotika dan Psikotropika 1988 (yang sudah diratifikasi dengan Undang-Undang No. 7 Tahun 1997), juga tidak ada ketentuan yang menegaskan bahwa permufakatan jahat (persekongkolan/conspiracy) harus diperberat pidananya. Kedua konvensi itu hanya menyatakan, bahwa "conspiracy to commit any of such offences, shall be punishable offences 
as provided in paragraf 1" (disingkat dari Pasal 22 ayat (2a) sub ii Konvensi Psikotropika 1971, yang mirip juga dengan redaksi Pasal 3 ayat (1c) sub iv Konvensi Pemberantasan Peredaran Gelap Narkotika dan Psikotropika 1988). Jadi permufakatan jahat dipidana sama dengan tindak pidana yang bersangkutan bukannya diperberat. Pemberatan pidana terhadap permufakatan jahat, tidak sesuai dengan sistem hukum pidana yang berlaku di Indonesia (baik di dalam maupun di luar KUHP). Padahal, dinyatakan dalam kedua konvensi itu, bahwa ketentuan-ketentuan konvensi seyogianyadiimplementasikan "dengan memperhatikan batasbatas peraturan perundang-undangan, sistem hukum dan undang-undang setempat dari suatu negara".

\section{Masalah Pertanggungjawaban Pidana Korporasi}

- Di dalam Undang-Undang Narkotika korporasi yang melakukan tindak pidana narkotika diatur dalam Pasal 130 ayat (1) dan ayat (2) Dalam undang-undang itu tidak ada ketentuan mengenai kapan atau dalam hal bagaimana korporasi dikatakan telah melakukan tindak pidana, dan kapan (dalam hal bagaimana) korporasi dapat dipertanggungjawabkan. Undang-undang itu hanya mengatur tentang siapa yang dipertanggungjawabkan.

- Menurut Undang-Undang Narkotika, dalam hal tindak pidana dilakukan oleh korporasi selain pidana penjara dan denda terhadap pengurusnya, pidana yang dapat dijatuhkan terhadap korporasi berupa pidana denda dengan pemberatan 3 (tiga) kali dari pidana denda sebagaimana dimaksud dalam Pasal 111 s.d Pasal 126 dan Pasal 129. Korporasi dapat juga dijatuhi pidana tambahan berupa : (a). Pencabutan izin usaha; dan/atau (b). Pencabutan status badan hukum.

- Tidak ada aturan umum mengenai pertanggung jawaban korporasi dalam Tindak Pidana Narkotika.

- Akhirnya dapat dikemukakan pula, bahwa apabila putusan pidana denda sebagaimana diatur dalam Undang-Undang ini tidak dapat dibayar oleh pelaku tindak pidana narkotika dan tindak pidana prekursor narkotika, pelaku dijatuhi pidana penjara paling lama 2 (dua) tahun sebagai pengganti pidana denda yang tidak dapat dibayar.

Sehubungan dengan aspek penal (hukum pidana) dalam rangka upaya penanggulangan tindak pidana narkotika melalui ketentuan Undang-undang No. 35 Tahun 2009 Tentang Narkotika, perangkat globalisasi yang juga digunakan dalam pemberantasan tindak pidana narkotika melalui Undang-undang Republik Indonesia No. 8 Tahun 1976 tentang Pengesahan konvensi Tunggal Narkotika 1961 beserta protokol tahun 1972 yang 
Ruben Achmad dan Neisa Angrum Adisti, Kebijakan Kriminal Dalam Pencegahan Dan Penanggulangan Narkotika Di Kota Palembang

mengubahnya dan Undang-undang Republik Indonesia No. 7 Tahun 1997 tentang Pengesahan Konvensi Perserikatan Perserikatan Bangsa-Bangsa tentang Pemberantasan Peredaran gelap Narkotika dan Psikotropika, 1988.

Kriminalisasi terhadap narkotika dalam Undang-Undang No. 35 Tahun 2009 proses penegakkannya akan dijalankan melalui mekanisme Sistem Peradilan Pidana (Criminal Justice System). Keadilan yang ingin diwujutkan melalui SPP adalah Keadilan Retributif (Retributif Justice) dan Just Desert Model (balasan yang setimpal). Dalam konteks Indonesia Penegakan Hukum Pidana harus memperhatikan rambu-rambu Hukum Nasional yang berfungsi sebagai Legal Frame work sebagaimana diatur dalam Undang-Undang Dasar 1945 dan Undang-Undang Pokok Kekuasaan Kehakiman. Oleh karena itu penegakan hukum pidana tidak hanya diartikan sebagai Legal certainty akan tetapi juga Substantif certainty. Secara umum konsep keadilan yang dijadikan sandaran dalam tulisan ini adalah Teori keadilan seperti yang dikemukakan oleh John Rawls, Keadilan adalah Fairness, konsep keadilan ini sejalan dengan keadilan menurut sistem hukum nasional.

Aspek Non Penal (pencegahan); merupakan aspek yang sangat strategisoleh karena tindak pidana (kejahatan) belum terjadi. Selain melakukan peneropongan apa yang telah dilakukan oleh aparat penegak hukum dalam melakukan pencegahan terhadap penyalahgunaan narkotika selama ini, juga kajian perencanaan ini akan menawarkan alternatif non penal lain sehubungan dengan penyalahgunaan narkotika. Pada dasarnya kajian non penal berangkat dari hasil identifikasi beberapa faktor yang potensial yang dapat mencetuskan penyalahgunaan narkotika. Upaya pencegahan itu dilakukan dengan memperbaiki faktor potensial tersebut.

Perencanaan Penanggulangan narkotika melalui aspek non penal yang telah dilakukan selama ini oleh aparat penegak hukum dan masyarakat secara tentatif dapat dikemukakan sebagai berikut :

1. Melakukan kegiatan dalam bentuk penyuluhan hukum (UU Narkotika) kepada para pelajar, mahasiswa dan pemuda;

2. Melakukan razia-razia terhadap tempat-tempat hiburan malam oleh aparat kepolisian;

3. Menyebarluaskan informasi kepada masyarakat melalui media massa cetak dan elektronik tentang bahaya mengkonsumsi narkotika;

4. Memperketat pengawasan penjualan bahan-bahan obat yang dapat digunakan untuk pembuatan narkotika; 
5. Memperketat penjagaan dan pengawasan pada tempat-tempat keluar masuk barang melalui pelabuhan darat, laut dan udara;

6. Membentuk Badan- Badan Anti Narkoba;

7. Meningkatkan Partisipasi masyarakat dalam upaya pencegahan dan penyalahgunaan obat-obat terlarang.

Apabila penanggulangan terhadap penyalahgunaan narkotika melalui sarana (penal dan non penal) dapat dijalankan secara integrated (keserempakan) maka diyakini angka kriminalitas penyalahgunaan narkotika di masyarakat cenderung akan menurun dan pada akhirnya akan berdampak positip bagi kemajuan bangsa Indonesia khususnya bagi kemajuan daerah (otonomi daerah).

Partisipasi masyarakat adalah peran aktif masyarakat untuk mewujutkan upaya pemberantasan penyalahgunaan dan peredaran gelap narkotika. Kewajiban masyarakat ialah melaporkan tentang terjadinya tindak pidana psikotropika kepada aparat penegak hukum. Di samping kewajiban itu, masyarakat mempunyai hak untuk mendapatkan jaminan keamanan dan perlindungan hukum dari aparat penegak hukum. Namun demikian, hak dan kewajiban masyarakat kelihatan amat terbatas, khususnya dalam menindak para pelaku kejahatan tersebut.

Hubungan antara hak dan kewajiban amat terkait dengan proses belajar mengajar dalam perubahan perilaku masyarakat terhadap aturan hukum. Beberapa definisi tentang arti belajar telah banyak dikemukakan oleh para ahli yang berbeda-beda pendiriannya, karena berlainan titik tolaknya. Sumadi Suryabrata, telah menyimpulkan hal-hal pokok belajar sebagai berikut :

1) Belajar itu membawa perubahan (dalam arti behavioral changes, aktual maupun potensial).

2) Perubahan itu pada pokoknya adalah didapatkannya kecakapan baru.

3) Perubahan itu terjadi karena usaha (dengan sengaja).

Beberapa konsepsi atau teori belajar menurut ahli-ahli yang mengikuti teori molekuler berpendapat bahwa perkembangan tingah laku itu tergantung kepada belajar. Ahliahli yang mengikuti paham molekuler bersifat atomistis, yakni cenderung untuk memikirkan sesuatu kesatuan dari segi susunannya. Kebiasaan-kebiasaan yang kompleks, misalnya dianggap sebagai kumpulan dari sejumlah refleks-refleks bersyarat. Transfer of training dianggap terjadi kalau ada unsur-unsur yang identik antara hal yang lama dan situasi yang baru atau sedang dihadapi. 
Peran serta masyarakat sangat dibutuhkan untuk memberantas peredaran gelap narkoba, karena tanpa dukungan masyarakat maka segala usaha, upaya dan kegiatan penegakan hukum akan mengalami kegagalan. Disinilah pentingnya mengubah sikap tingkah laku dan kepedulian masyarakat terhadap pencegahan dan penaggulangan tindak pidana narkoba.

Penyuluhan hukum harus menggunkan strategi yang tepat dan efektif, sehingga masyarakat benar-benar memahami tentang bahaya narkoba dan akan melakukan action anti narkoba. Penerapan sanksi pidana yang berat kepada para pelaku kejahatan akan memberikan deterent effect dan sekaligus berdampak pada law of effect serta dampak sosialnya, yakni sebagai wahana pembelajaran publik, sehingga masyarakat akan sadar betul tentang pentingnya menjauhi penyalahgunaan narkoba.

Pembelajaran publik berdasarkan pengamatan terhadap konsistensi penegakan hukum dan penerapan sanksi pidana berat, akan tercipta norma-norma sosial yang dijunjung tinggi, sehingga norma-norma sosial tersebut sebagai sarana pengendalian sosial, yang dilembagakan kembali kepada norma-norma hukum untuk dipatuhi dan ditaati.

Berdasarkan teori belajar di atas, peran serta masyarakat dapat dianalisis melalui aspek pencegahan tindak pidana narkoba, yakni bagaimana upaya masyarakat dapat melakukan pengawasan terhadap semua aktivitas warga masyarakat agar tidak menyalahgunakan penggunaan narkoba secara illegal.

Dengan demikian, kata-kata kunci peran serta masyarakat dalam kaitan dengan pemberantasan penyalahgunaan narkotika, tujuannya ialah bagaimana upaya untuk membangun sistem pengendalian sosial tersebut melalui proses belajar. Masyarakat sebagai suatu sistem sosial, yaitu suatu sistem yang hidup dipastikan akan menghadapi sejumlah masalah dan harus dapat diatasi untuk memungkinkan sistem sosial tersebut bisa melangsungkan kehidupannya.

Sesuai rumusan Undang-Undang Nomor 35 Tahun 2009 dalam Pasal 106 dikatakan bahwa :Hak masyarakat dalam upaya pencegahan dan pemberantasan penyalahgunaan dan peredaran gelap narkotika dan prekursor narkotika diwujutkan dalam bentuk : (a). Mencari, memperoleh, dan memberikan informasi adanya dugaan telah terjadi tindak pidana narkotika dan prekursor narkotika (b). Memeproleh pelayanan dalam mencari masyarakat wajib melaporkan kepada pihak yang berwenang bila mengetahui tentang narkoba (psikotropika) yang disalahgunakan dan/atau dimiliki secara tidak sah. Kewajiban melaporkan ini merupakan salah satu bentuk atau wujut peran serta masyarakat dalam pemberantasan 
penyalahgunaan dan peredaran gelap narkoba (psikotropika). Ketentuan ini apabila dilanggar dikenakan sanksi pidana, oleh sebab itu diperlukan pemahaman terhadap hak dan kewajiban masyarakat dalam prevensi kejahatan ini.

Penggunaan orang-orang yang terlibat atau dilibatkan secara langsung oleh penegak hukum,baik sebagai informan maupun yang terlibat dalam pembelian terselubung, dan/ atau penyerahan yang diawasi, perlu mendapatkan prioritas jaminan keamanan dan perlindungan hukum oleh penegak hukum. Dalam hal ini, perlu diperjelas apa yang dimaksud dengan jaminan keamanan dan perlindungan.

Keamanan berasal dari kata "aman", yang memberikan makna, terbebas dari perasaan takut dari gangguan baik fisik maupun psikis, adanya rasa kepastian dan bebas dari kekhawatiran, keragu-raguan, ketakutan, perasaan dilindungi dari segala macam bahaya dan perasaan kedamaian, ketenteraman lahiriyah dan batiniah.

Sebenarnya kondisi aman seperti tersebut di atas itulah yang merupakan kendala masyarakat dalam berkomunikasi dengan aparat penegak hukum, khususnya dengan aparat kepolisian, berkaitan dengan kewajiban melaporkan tentang suatu peristiwa tindak pidana. Secara empiris masyarakat yang melapor ke polisi justru menimbulkan rasa kekhawatiran, kejenuhan, dan proses yang bertele-tele sehingga menyita waktu si pelapor.

Manusia dapat dipandang sebagai suatu organisme, dan manusia selalu melakukan beberapa aktivitas tertentu dalam kaitan dengan kehidupan sosialnya, yakni untuk mempertahankan diri (self maintenance), melakukan pengawasan dan pengendalian diri (self control), terkait dengan peroses timbal balik (prosess of feed back) serta meakukan komunikasi informasi (communication of information) yang bertujuan untuk menjaga keseimbangan (equilibrium) secara homeostaalamtis dalam tatanan kehidupan sosialnya. Hubungan organisme manusia dengan manusia lainnya dapat dilihat dalam hubungan sibernatika. Usaha mempertahankan diri, melakukan pengawasan dan pengendalian, proses timbal balik, melakukan komunikasi informasi merupakan suatu faktor menciptakan kondisi. Dalam kaitan dengan peran serta masyarakat dalam penanggulangan narkoba, polisi mengakui masyarakat enggan melaporkan narkoba kepada petugas.

Pandangan masyarakat ini disebabkan karena kurang adanya tanggapan dari kepolisian, padahal selama ini masyarakat telah memberikan informasi dan penggalangan kekuatan untuk bertindak sendiri memberantas narkoba. Merasa tidak ditanggapi masyarakat menjadi curiga bahwa polisi ikut terlibat atau mengambil keuntungan material dari penyalahgunaan narkoba. Merasa tidal ditanggapi masyarakat menjadi curiga bahwa polisi 
Ruben Achmad dan Neisa Angrum Adisti, Kebijakan Kriminal Dalam Pencegahan Dan Penanggulangan Narkotika Di Kota Palembang

ikut terlibat atau mengambil keuntungan material dari penyalahgunaan narkoba. Berdasarkan fenomena di atas, diperlukan sistem penyebaran arus informasi dan penguatan untuk membangkitkan motivasi masyarakat

\section{Kebijakan Kriminal Dalam Pencegahan Dan Penindakan Kejahatan Narkotika Di Indonesia}

Sumatera Selatan merupakan wilayah darurat penyalahgunaan Narkotika hal ini dapat dilihat dari jumlah kasus narkoba yang ditangani oleh direktorat reserseTindak pidana penyalahgunaan Narkotika meningkat di 3 tahun terakhir. Hal tersebut tergambarkan dalam tabel di bawah ini:

\section{TABEL I JUMLAH UNGKAP KASUS TINDAK PIDANA NARKOBA DIREKTORAT RESERSE NARKOBA KEPOLISIAN DAERAH SUMSEL DAN JAJARAN TAHUN 2017 SAMPAI DENGAN TAHUN 2019}

\begin{tabular}{|c|c|c|c|c|c|c|}
\hline \multirow[t]{2}{*}{ No } & \multirow[t]{2}{*}{ TAHUN } & \multirow{2}{*}{$\begin{array}{l}\text { JUML } \\
\text { AH LP }\end{array}$} & \multirow{2}{*}{$\begin{array}{c}\text { JUMLAH } \\
\text { TERSANGKA }\end{array}$} & \multicolumn{3}{|c|}{ JUMLAH BARANG BUKTI } \\
\hline & & & & GANJA & SABU & EKSTASI \\
\hline 1 & 2 & 3 & 4 & 5 & 6 & 7 \\
\hline 1 & 2017 & 1.759 & 2.410 & $\begin{array}{l}403.258,515 \\
\text { Gram } \\
2 \text { Linting } \\
67 \text { Batang } \\
71 \text { Paket } \\
2 \text { Paket Sedang }\end{array}$ & $\begin{array}{l}55.056,825 \\
\text { Gram }\end{array}$ & $\begin{array}{l}41.0361 / 2 \\
\text { Butir } \\
445 \text { Butir } \\
\text { Happy Five }\end{array}$ \\
\hline 2 & 2018 & 1.911 & 2.477 & $\begin{array}{l}1.139 .110,54 \\
\text { Gram } \\
\text { Tembakau } \\
\text { Gorilla } \\
\text { Berat } 109,85 \\
\text { Gram } \\
\end{array}$ & $\begin{array}{l}88.530,452 \\
\text { Gram }\end{array}$ & $\begin{array}{l}42.220 \\
\text { Butir }\end{array}$ \\
\hline 3 & $\begin{array}{l}2019 \\
(\mathrm{JAN}- \\
\mathrm{OKT})\end{array}$ & 1.352 & 1.764 & $\begin{array}{l}2.286 .572 \\
\text { Gram }\end{array}$ & $\begin{array}{l}94.071,337 \\
\text { Gram } \\
250 \text { Paket }\end{array}$ & $\begin{array}{l}39.787 \\
\text { Butir } \\
258,13 \\
\text { Gram }\end{array}$ \\
\hline
\end{tabular}

Keseriusan pemerintah dalam menangani narkoba ini dilakukan melalui kebijakan berupa produk-produk hukum misalnya undang-undang, peraturan menteri, peraturan pemerintah, hingga peraturan-peraturan yang dikeluarkan oleh tiap provinsi dan kabupaten/kota yaitu:

1. Undang-Undang Nomor 35 Tahun 2009 Tentang Narkotika;

2. Peraturan Presiden Nomor 23 Tahun 2010 Tentang Badan Narkotika Nasional; 
3. Peraturan Menteri Kesehatan No. 44 Tahun 2019 Tentang Perubahan Penggolongan Narkotika. Peraturan ini merupakan peraturan yang baru saja dikeluarkan, menggantikan Peraturan Menteri Kesehatan No. 50 Tahun 2018. Salah satu alasan dikeluarkan Permenkes ini adalah terdapatnya zat psikoaktif baru (new psychoactive substance) yang berpotensi penyalahgunaan dan membahayakan kesehatan masyarakat yang belum termasuk dalam golongan narkotika sebagaimana diatur dalam Lampiran I Undang-Undang Nomor 35 Tahun 2009 tentang Narkotika dan Peraturan Menteri Kesehatan Nomor 50 Tahun 2018 tentang Perubahan Penggolongan Narkotika. Adapun Permenkes ini menambah Narkotika Golongan I menjadi 175 dimana sebelumnya adalah 161. Sedangkan Narkotika Golongan II dan III tetap; ${ }^{10}$

4. Peraturan Menteri Dalam Negeri No. 12 Tahun 2009 Tentang Fasilitasi Pencegahan dan Pemberantasan Penyalahgunaan dan Peredaran Gelap Narkotika dan Prekursor Narkotika;

5. Peraturan Pemerintah No. 40 Tahun 2013 Tentang Pelaksanaan UU Narkotika;

6. Peraturan Daerah Kota Palembang Nomor 1 Tahun 2003 Tentang Pengaturan Operasional Tempat Hiburan;

7. Keputusan Walikota Palembang Nomor 456 Tahun 2017 Tentang Pembentukan Satuan Tugas Pencegahan Penyalahgunaan dan Peredaran Gelap Narkotika Kota Palembang;

8. Keputusan Walikota Palembang Nomor 539 Tahun 2017 Tentang Pembentukan Panitia Pelaksana Razia Penyalahgunaan dan Peredaran Gelap Narkotika dan Obat-obatan Terlarang;

9. Keputusan Walikota Nomor 198 Tahun 2018 Tentang Pembentukan Panitia Pelaksana Penyuluhan dan Pembinaan Bahaya Narkotika Bagi Masyarakat Kota Palembang.

Selain dengan peraturan perundang-undangan upaya penanggulangan dan pecegahan Narkotika dilakukan secara sinergi beberapa lembaga yang terkait satu sama lain ,P4GN adalah Pemberantasan Peredaran Gelap Narkoba dan Perkusor yang merupakan suatu program penanggulangan pencegahan narkotika. Pencegahan Pemberantasan Penyalahgunaan dan Peredaran Gelap Narkoba (P4GN) adalah upaya sistematis berdasarkan data

\footnotetext{
${ }^{10}$ Farmasetika.com, Menkes Kembali Golongan Narkotika, https://farmasetika.com/2019/10/23/menkes-kembali-ubah-golongan-narkotika-permenkes-no-44-tahun-2019/ diakses pada 7 November 2019.
} 
Ruben Achmad dan Neisa Angrum Adisti, Kebijakan Kriminal Dalam Pencegahan Dan Penanggulangan Narkotika Di Kota Palembang

penyalahgunaan narkoba yang tepat dan akurat, perencanaan yang efektif dan efisien dalam rangka mencegah, melindungi dan menyelamatkan warga negara dari ancaman bahaya penyalahgunaan narkoba untuk itu diperlukan kepedulian dari seluruh instansi pemerintah dalam upaya tersebut dengan mendorong satgas di instansi pemerintah menjadi pelaku P4GN secara mandiri. ${ }^{11}$ pentingnya pemberdayaan masyarakat bersama instansi pemerintah dalam program P4GN adalah dalam rangka upaya memobilisasi seluruh sumber daya yang ada untuk meningkatkan keberdayaan masyarakat dalam rangka penanganan narkoba yang meliputi aspek pencegahan, rehabilitasi dan pemberantasan dijabarkan dalam tabel berikut ini:

\section{TABEL II}

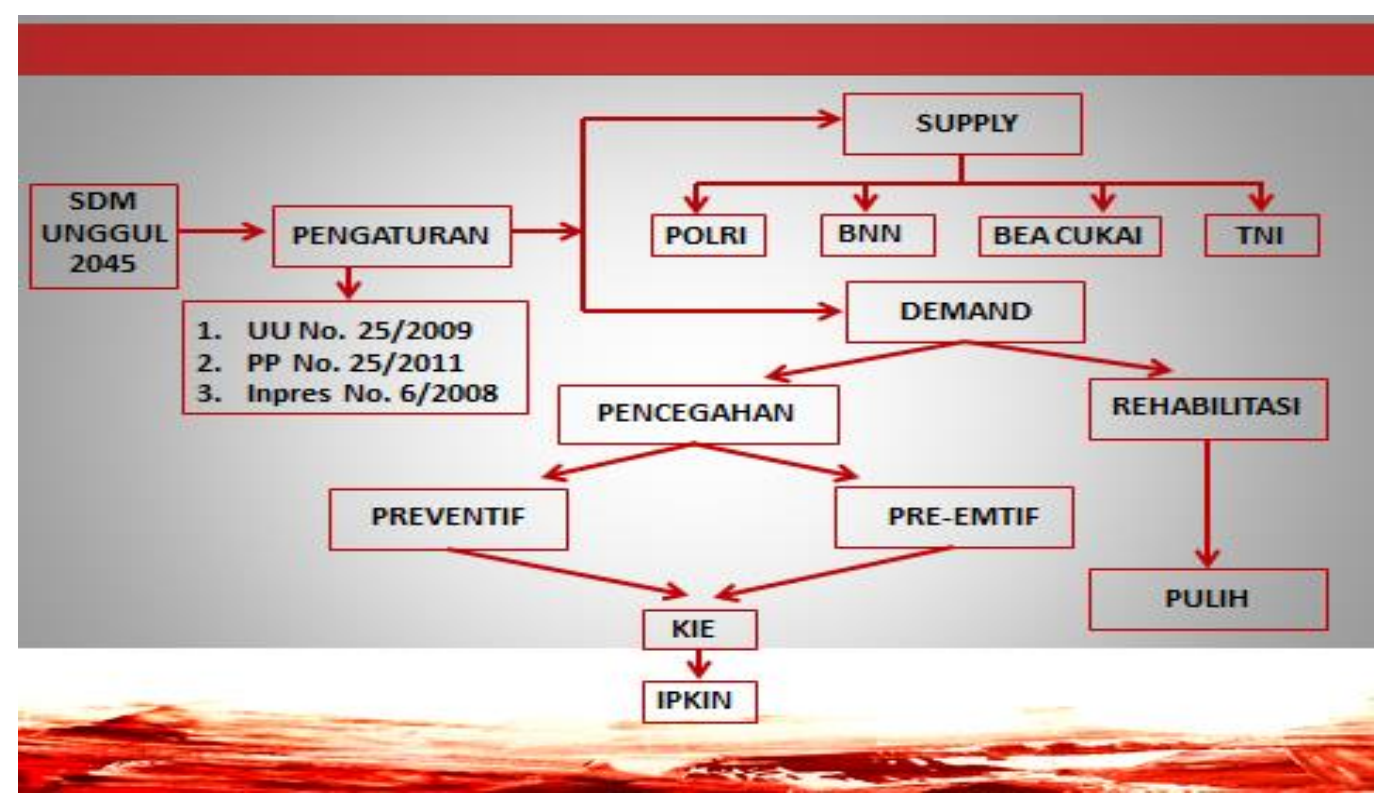

P4GN terdiri dari pemberantasan Suply dan Demand. Tujuan dari P4GN tersebut adalah SDM Unggul tahun 2045. Maksud suply disini adalah pemberantasan narkotika itu sendiri. Adapun lembaga yang bertugas dalam pemberantasan narkotika adalah POLRI, BNN, BEA Cukai, TNI.

Suply disini adalah bagian pemberantasan penyalahgunaan narkotika yaitu :

11 Wawancara dengan Edi Nugroho, Kabag Binopnal Ditresnarkoba polda Sumselpada tanggal 15 Nopember 2019 pukul 13.00 


\section{TABEL III}
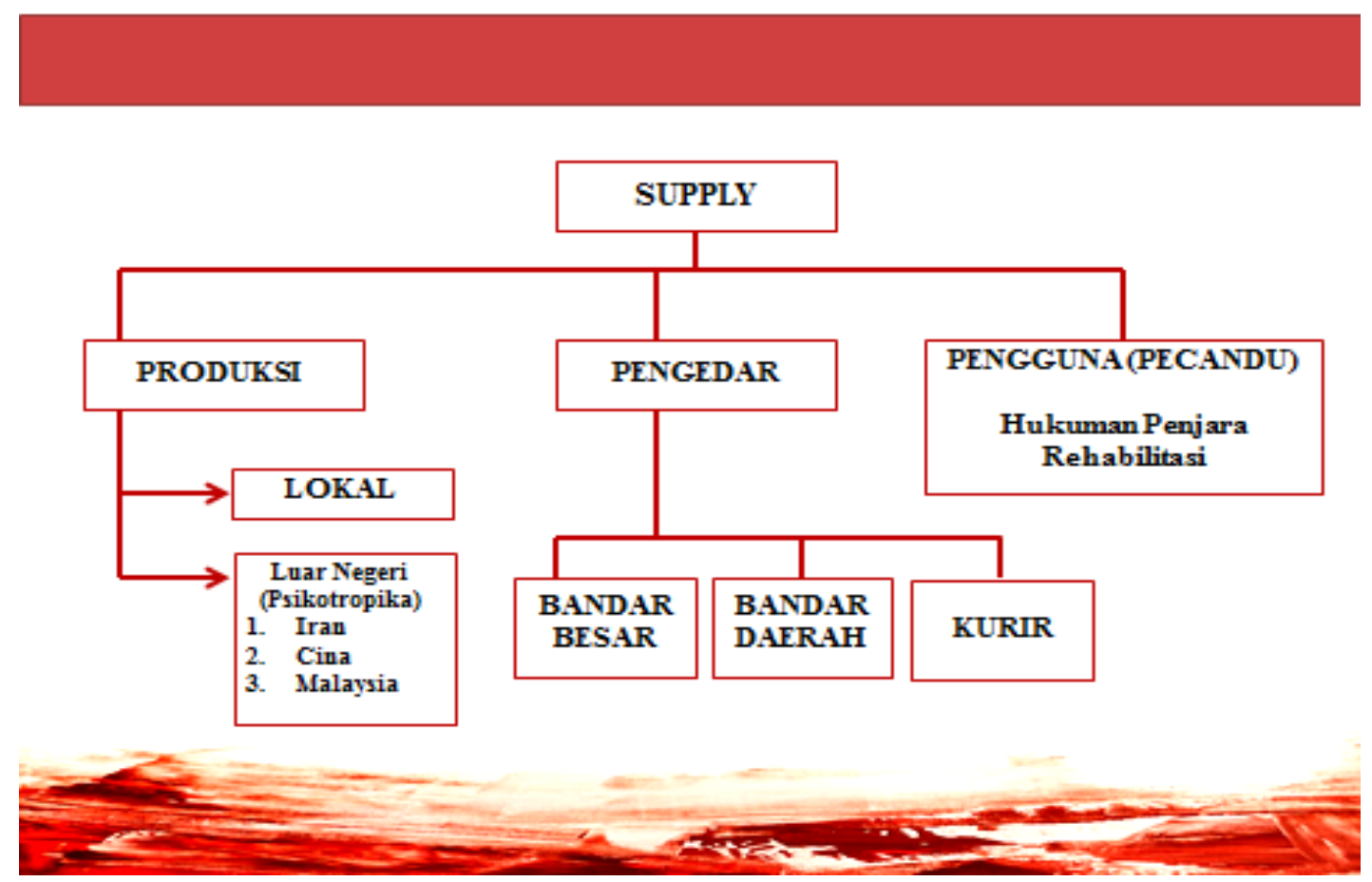

Pemberantasan yang dilakukan terdiri dari pemberantasan:

1. Produksi .

2. Pengedar.

3. Pemakai.

Pemberantasan produksi narkotika dapat berupa pemberantasan pabrik narkotika ataupun pemusnahan ladang ganja. Pemberantasan Produksi dapat dibagi 2 yaitu pemberantasan produksi lokal maupun luar negeri seperti di Negara iran, Cina , Malaysia. ${ }^{12}$ Pemberantasan pengedar dibagi menjadi pemberantasan bandar besar, bandar daerah maupun pemberantasan kurir narkotika. Pemberantasan pemakai (pecandu ) dapat dilakukan Pidana penjara maupun Sanksi tindakan Rehabilitasi.

Melihat pada program upaya pemberantasan BNN, BNNP Sumsel telah melakukan berbagai upaya dalam menanggulanginya. Mulai dari sosialisasi-sosialisasi hingga rehabilitasi, serta meningkatkan sinergitas kemitraan dengan instansi terkait lainnya. Pada 28 Oktober 2019 waktu dini hari lalu, Tim Fleet One Quick Response (F1QR) Lanal Palembang berhasil meringkus dua orang pengedar sabu-sabu seberat 79kilogram saat mengendarai

12 Wawancara dengan Edi Nugroho, Kabag Binopnal Ditresnarkoba polda Sumselpada tanggal 15 Nopember 2019 pukul 13.00 
speedboat dengan kecepatan tinggi melintasi perairan Sungai Sungsang Kabupaten Banyuasin Sumatera Selatan. Aksi penangkapan ini dilakukan seusai Lanal Palembang memperoleh informasi terkait pengiriman paket narkoba dari Lanal Batam. Pasca penangkapan, kedua pengedar narkoba ini bersama barang buktinya langsung diserahkan ke Badan Narkotika Provinsi Sumatera Selatan untuk diselidiki lebih lanjut. ${ }^{13}$ Di sisi lain, selain kemitraan antar instansi yang diperkuat, masyarakat juga memiliki peran besar dalam membantu upaya pemberantasan narkotika di Indonesia, khususnya dalam hal ini pengedaran di wilayah Kota Palembang dan sekitarnya. Pada 26 Agustus 2019 lalu, turut telah dilakukan penangkapan di daerah Komplek Bandara Mas, terhadap salah satu pengedar narkoba di Kota Palembang. Barang bukti yang diamankan berupa narkoba jenis sabu seberat 20 kilogram dan pil ekstasi sebanyak 18.800 butir. Disinyalir barang haram ini akan disimpan di sebuah gudang kosong di kawasan Tangga Buntung milik seseorang berinisial S yang merupakan bandar narkoba kelas kakap di Kota Palembang. Kepala BNNP Sumsel turut mengatakan bahwa upaya penangkapan ini tidak terlepas dari informasi yang diberikan oleh masyarakat. ${ }^{14}$

Berbeda dengan suply yang merupakan program pemberantasan demand lebih kearah pencegahan maupun perbaikan diri pelaku.Demand dilakukan dengan 2(dua) cara yaitu :

a. Rehabilitasi Tujuan dari rehabilitasi adalah pulih., walaupun tidak bisa mengembalikan pada kedaan semula (sembuh) . Lembaga Rehabilitasi dapat dibagi menjadi 2 (dua) yaitu:

- Lembaga rehabilitasi Eksternal

- Lembaga rehabilitasi Internal

Lembaga rehabilitasi ekternal adalah lembaga rehabilitasi non pemerintah (yang diselenggarakan oleh masyarakat) yang menangani kasus pengguna narkotika seperti : lembaga rehabilitasi Ar- Rahman dan lembaga rehabilitasi Mitra Mulya.

b. Pencegahan.

Pencegahan terdiri dari prefentif dan preemtif. Penyuluhan merupakan salah satu upaya pencegahan penyalahgunaan Narkotika. Penyuluhan yang dilakukan oleh POLDA Sumsel dilakukan 1(satu) bulan sekali dengan audien 100 (seratus)

\footnotetext{
${ }^{13}$ Liputa6, Berita Harian (30 Oktober 2019): Incar 2 Pengedar 79kg Sabu, Aksi Kejar-kejaran di Perairan Sumsel Tak Terelakkan, https://www.liputan6.com/regional/read/4098274/incar-2-pengedar-79-kg-sabu-aksikejar-kejaran-di-perairan-sumsel-tak-terelakkan, diakses pada 7 November 2019.

${ }^{14}$ Liputan6, Berita Harian (28 Agustus 2019): Gudang Kosong di Palembang Jadi Brankas Sabu Seberat 20 Kilogram, https://www.liputan6.com/regional/read/4048512/gudang-kosong-di-palembang-jadi-brankassabu-seberat-20-kilogram, diakses pada 7 November 2019.
} 
orang. Penyuluhan memberikan KIE (Komunikasi Informasi dan Edukasi) ${ }^{15} \mathrm{KIE}$ disini tujuannya adalah membentengi orang agar tidak terjadi Narkotika.

KIE merupan kegiatan penyebaran ikomunikasi , informasi dan edukasi narkotika yang dilakukan oleh BNN . Pada tahun 2018 KIE dilakukan 31 kali di wilayah Sumatera Selatan. Sebaran Diseminasi Informasi dilakukan 289 kali dengan audiens berjumlah 157.339. dengan jumlah relawan 350 dan jumlah penggiat $585^{16}$

Upaya yang paling tepat dalam pencegahan dan penyalahgunaan narkotika adalah upaya demand yang menitik beratkan pada perbaikan pelaku yaitu penyuluhan dan juga rehabilitasi. Dibandingkan penjara, rehabilitasi lebih tepat dilaksanakan bagi pengguna narkotika. Dikarenakan efek negatif penjara yang belum tentu memperbaiki keadaan pelaku. ${ }^{17}$ Namun pada kenyataannya, hakim sangat jarang memutus dengan putusan rehabilitasi. Apabila diteliti darin 3 (tiga) putusan hakim pada Pengadilan Negeri Palembang Apabila diteliti dari 3(tiga) putusan hakim pada pengadilan Negeri Palembang dapat dijabarkan sebagai berikut:

Pada perkara 1134/Pid.Sus/2016/PN.Plg yang menjerat seorang terdakwa yang diancam pidana dalam Pasal 112 ayat (1) Undang-Undang Nomor 35 Tahun 2009 Tentang Narkotika, yaitu atas perbuatannya "tanpa hak atau melawan hukum memiliki, menyimpan, menguasai, atau menyediakan Narkotika golongan I" tersebut tanpa izin dari pihak yang berwenang untuk itu atau tidak untuk dipergunakan dalam kepentingan pengobatan maupun ilmu pengetahuan. Tim Jaksa Penuntut Umum kemudian menuntut penjatuhan pidana terhadap terdakwa berupa pidana penjara selama 5 (lima) tahun dan denda sebesar Rp 800.000.000,- Subsidair 6 (enam) bulan penjara (dikurangi selama terdakwa berada dalam masa tahanan). Adapun pertimbangan Tim Majelis Hakim dalam menjatuhkan straf terhadap terdakwa ialah dengan memperhatikan unsur-unsur yang didakwakan pada Pasal 112 ayat (1) Undang-Undang Narkotika .

Pada putusan Hakim kedua, berdasarkan Perkara Nomor 1025/Pid.Sus/2016/PN.Plg pada Pengadilan Negeri Klas I A Palembang atas nama terdakwa Doyok Saputra. Terdakwa Doyok setelah dinyatakan terbukti secara sah dan meyakinkan bersalah "melakukan percobaan atau permufakatan jahat untuk melakukan tindak pidan atanpa hak atau melawan hukum memiliki atau menyediakan Narkotika Golongan I bukan tanaman", sehingga atas

15 Wawancara dengan Edi Nugroho, Kabag Binopnal Ditresnarkoba polda Sumselpada tanggal 15 Nopember 2019 pukul 13.00

${ }^{16}$ Agustinus Widdy., dkk, Op.cit, hlm.25

${ }^{17}$ Wawancara dengan Nanang iskandar, Polda Sumsel pada tanggal 15 Nopember 2019 
pertimbangan majelis hakim menjatuhkan pidana sebagaimana tuntutan Jaksa Penuntut Umum berdasarkan Pasal 112 (1) UU No. 35 Tahun 2009 Tentang Narkotika Jo. Pasal 132 ayat (1) UU No. 35 Tahun 2009 Tentang Narkotika. terdakwa Ona Binti Yusuf dijatuhi straf penjara dan denda dibatas minimal yaitu penjara selama 4 tahun dan denda Rp 800.000.000,-,

Dapat dibandingkan dalam Pasal yang mengatur hukuman dengan putusan yang diberikan hakim, bahwa terdakwa Doyok Saputra dijatuhi hukuman penjara di atas batas minimal yaitu selama 5 (lima) setengah tahun dan denda minimal sesuai batasan undangundang yaitu sebesar Rp 800.000.000,- (delapan ratus juta rupiah).

Atas pemberian vonis tersebut, pertimbangan hakim dalam hal yang memberatkan ialah perbuatan terdakwa tidak mendukung program pemerintah dalam memberantas tindak pidana narkotika, namun hal yang meringankan ialah kerjasama/kelakuan baik terdakwa selama proses persidangan berlangsung.

Pada putusan selanjutnya pada perkara Nomor 998/Pid.Sus/2016/PN.Plg pada Pengadilan Negeri Klas I A Palembang atas nama terdakwa Adi Leonard Sitepu.

Terdakwa Adi Leonard Sitepu setelah dinyatakan terbukti secara sah dan meyakinkan bersalah "menyalahgunakan Narkotika Golongan I bagi diri sendiri”, sehingga atas pertimbangan majelis hakim menjatuhkan pidana sebagaimana tuntutan Jaksa Penuntut Umum berdasarkan Pasal 127 ayat (1) UU No. 35 Tahun 2009 Tentang Narkotika. Atas perbuatan terdakwa, memperhatikan Psal 127 ayat (1) huruf a Undang-Undang No. 35 Tahun 2009 Tentang NARKOTIKA DAN Undang-Undang No. 8 Tahun 1981 Tentang Hukum Acara Pidana, maka majelis hakim menjatuhi terdakwa dengan hukuman pidana penjara selama 1 (satu) tahun dan 4 (empat) bulan.

Pada putusan nomor 3 terjadi ketimpangan antara kebijakan hukum dengan implementasi hukum yang ada. Padahal, dalam UU Narkotika ini hakim diberi kewenangan tambahan secara khusus dalam memeriksa perkara pecandu (perkara penyalah guna dalam keadaan ketergantungan) yakni hakim 'dapat' memutuskan untuk memerintahkan terdakwa menjalani rehabilitasi jika terbukti bersalah dan menetapkan untuk memerintahkan menjalani rehabilitasi jika tidak terbukti bersalah (Pasal 103). Ini artinya, terbukti atau tidak dalam sidang pengadilan, hukuman bagi terdakwa tetap berujung pada satu titik yakni rehabilitasi. $^{18}$

18 Anang Iskandar, Tulisan seorang Kepala BNN Periode 2012-2015, Kabareskrim Polri 2015-2016 dan Dosen Narkotika pada Universitas Trisakti; Hakim Wajib Memvonis Rehabilitasi bagi Penyalah Guna Narkotika (16 November 2017), https://mediaindonesia.com/read/detail/132303-hakim-wajib-memvonisrehabilitasi-bagi penyalah-guna-narkotika. 
Kewenangan berdasarkan regulasi ini bukan berarti tidak bisa digunakan dalam memutuskan perkara pecandu belaka. Lema atau diksi 'dapat' itu artinya kewenangan tambahan yang memang telah diberikan undang-undang 'khusus' yang sifatnya wajib karena Pasal 127 ayat 2 dari Undang-Undang tentang Narkotika itu berbunyi "Hakim dalam memeriksa perkara penyalah guna untuk diri sendiri (Pasal 127 ayat 1) wajib memperhatikan Pasal 54, 55, 103”. Kewenangan tambahan terhadap lembaga pengadilan itu ialah untuk dapat memutuskan dan memerintahkan penyalah guna narkoba melakukan rehabilitasi. Juga, menetapkan untuk memerintahkan rehabilitasi ini bukan sekadar dicomot dari dunia antah berantah, melainkan berasal dari konvensi tunggal narkotika pada 1961 serta Protokol 1972 yang seharusnya segera mengganti wajah pengambilan keputusan pengadilan di seluruh dunia, termasuk Indonesia, terutama terkait dengan para penyalah guna narkotika. Dari konvensi itu juga pemerintah mengadopsinya melalui UndangUndang No 8 Tahun 1976. Pada akhirnya, regulasi itulah yang menjadi dasar dari lahirnya Undang-Undang Narkotika kita saat ini. ${ }^{19}$

Penyalahguna memang dikategorikan sebagai kriminal. Namun, karena 'khusus'nya Undang-Undang No 35 Tahun 2009 tentang Narkotika, penyalah guna dilabeli regulasi sebagai orang sakit yang mengidap penyakit adiksi atau kecanduan yang hanya pulih atau dapat disembuhkan dengan cara merehabilitasinya.Rehabilitasi penyalahguna ini kemudian menjadi domain dari Kementerian Kesehatan untuk melakukan rehabilitasi medis, Kementerian Sosial untuk rehabilitasi sosial, dan Badan Narkotika Nasional untuk rehabilitasi medis dan rehabilitasi sosial. Perkara penyalahguna ini apabila dimintakan assessment atau diperiksa tim assessment atau dokter ahli (visum et repertum) berubah predikatnya menjadi perkara pecandu (penyalah guna dan dalam keadaan ketergantungan narkotika), yang menurut Pasal 54 Undang-Undang Narkotika kita wajib merehabilitasi, bukan dengan mengirimkannya ke penjara. Itulah sebabnya kenapa hakim diberi kewenangan tambahan untuk memberi hukuman rehabilitasi, baik bagi yang terbukti bersalah maupun bagi yang tidak terbukti bersalah. Berdasarkan Pasal 103 ayat (2) Undang-Undang No 35 Tahun 2009 tentang Narkotika, hukuman rehabilitasi sama dengan hukuman penjara menurut konvensi tunggal narkotika yang sudah diamendemen. Hukuman rehabilitasi jelas lebih bermanfat bagi penyalah guna, keluarga, bangsa, dan negara daripada hukuman penjara. Sederhananya, hukuman penjara bagi penyalah guna justru tidak menyembuhkan, justru masyarakat malah dirugikan secara spritual dan material. 
Negara juga malah akan menghasilkan generasi tidak sehat secara terus-menerus dan sistemis sehingga menyuburkan bisnis narkotika. ${ }^{20}$

Institute for Criminal Justice Reform (ICJR) mencatat, dalam Meninjau Rehabilitasi Pengguna Narkotika dalam Praktik Peradilan, pandangan pengguna narkotika sebagai pelaku kejahatan masih lebih dominan dibandingkan pendekatan kesehatan dan penyembuhan terhadap ketergantungan narkotika. Sejumlah pasal dalam UU Narkotika yang sering dikenakan oleh penuntut umum, baik dalam dakwaan maupun tuntutan, baik dari pasal 111, pasal 112, pasal 114, maupun pasal 127 UU Narkotika. ICJR kemudian melakukan riset terhadap 30 putusan terkait pidana narkotika Pengadilan Negeri Surabaya menyebutkan sebanyak 48 persen kasus menggunakan pasal 111 atau pasal 112 baik sebagai dakwaan pertama, primer, tunggal atau dakwaan kedua serta subsidair. Dalam kategori tersebut, pasal 127 digunakan sebanyak 33 persen dan pasal 114 digunakan sebanyak 18 persen. Meski penggunaan pasal 111 atau 112 dibanding pasal 127 terpaut 15 persen, ICJR mencatat ketika jaksa menggunakan pasal 127, mereka tetap mencantumkan pasal 111, 112 atau 114. Pasal 127 lebih banyak ditempatkan di posisi dakwaan kedua atau subsidair. "Ini menunjukkan bahwa jaksa masih ingin menjerat terdakwa dengan penggunaan pasal 111, 112 atau 114, yang secara unsur lebih mudah untuk dibuktikan," sebut laporan ICJR.Berdasarkan data yang dihimpun ICJR, pasal 111 atau 112 dicantumkan sebagai dakwaan primer/pertama, sebanyak 63 persen. Sementara pasal 114 dicantumkan sebanyak 37 persen. Tragisnya, pasal 127 tidak pernah dicantumkan sebagai dakwaan primer atau pertama.Hal tersebut berdampak pada vonis yang dijatuhkan hakim. Dari 30 putusan, hanya 6 persen yang menjatuhkan hukuman rehabilitasi bagi terdakwa. Seluruh tindakan rehabilitasi, hanya diberikan pada anak. ${ }^{21}$

Padahal di satu sisi, semangat untuk tidak hanyamenjatuhkan sanksi penjara pada pelaku penyalahgunaan narkoba melainkan melakukan rehabilitasi telah muncul dalam sistem hukum Indonesia. Hal itu tercantum dalam Surat Edaran Mahkamah Agung (SEMA) Nomor 04 Tahun 2010 dan SEMA Nomor 04 Tahun 2010.Dalam surat edaran tersebut, Mahkamah Agung menetapkan lima kualifikasi pelaku penyalahgunaan, korban penyalahgunaan, dan pecandu narkotika yang dapat ditempatkan di rehabilitasi. Pertama, penangkapan terhadap terdakwa dilakukan secara tertangkap tangan. Kemudian yang kedua, pada saat tertangkap tangan tersebut ditemukan barang bukti pemakaian 1 hari narkotika dengan jenis dan bobot tertentu.Ketentuan yang ketiga juga mengharuskan terbitnya surat uji laboratorium dengan

21 Husein Abdulsalam, Berita Harian Online Tirto.id, Dilema Hukuman Rehabilitasi Narkoba (3 September 2017), https://tirto.id/dilema-hukuman-rehabilitasi-narkoba-cvF8. 
hasil pemeriksaan positif menggunakan narkotika atas permintaan penyidik. Kualifikasi keempat, diperlukan surat keterangan dari dokter jiwa/psikiater pemerintah yang ditunjuk oleh hakim. Sedangkan yang kelima, tidak terdapat bukti bahwa yang bersangkutan terlibat dalam peredaran gelap narkotika. Surat edaran tersebut diterbitkan dalam rangka menyamakan persepsi dalam penerapan SEJA RI No. SE-002/A/JA/02/2013 tentang Penempatan Korban Penyalahgunaan Narkotika ke lembaga Rehabilitasi Medis dan Rehabilitasi Sosial.Dalam SEJA tersebut disebutkan pasal-pasal dalam Bab IX UU Narkotika menegaskan bahwa pecandu narkotika dan korban penyalahgunaan narkotika wajib menjalani rehabilitasi medis dan rehabilitasi sosial. Ketentuan tersebut telah dijabarkan di dalam PP No. 25 Tahun 2011 tentang Pelaksanaan Wajib Lapor Pecandu Narkotika. ${ }^{22}$

Undang-Undang Nomor 35 Tahun 2009 Tentang Narkotika ini dibentuk dengan tujuan tegas terhadap faktor demand reduction (penyalah guna, pecandu) agar dapat dicegah, dilindungi, diselamatkan dan dijamin untuk mendapatkan upaya rehabilitasi. Sedangkan terhadap faktor supply demand (pengedar dan kejahatan yang berhubungan dengan peredaran) dapat diberantas. Sehingga visi penegakkan hukum bersifat rehabilitatif terhadap penyalah guna dan visi penegak hukum bersifat represif kepada pengedar. Terhadap demand reduction digambarkan melalui kegiatan: ${ }^{23}$

Pertama, pencegahan penyalahgunaan narkotika, ditujukan untuk membentengi masyarakat agar terlibat penyalahgunaan narkotika, sasarannya adalah masyarakat yang belum pernah terlibat dengan penyalahgunaan narkotika agar tidak menjadi penyalah guna, dan tidak menjadi pengedar. Kedua, rehabilitasi penyalah guna dan pecandu narkotika. Penyalah guna untuk diri sendiri digambarkan sebagai penjahat diancam dengan pidana pidana ringan maximum 4 tahun penjara. Penyalahguna tersebut diwajibkan untuk melaporkan pada rumah sakit yang ditunjuk agar sembuh, bagi yang melaksanakan wajib lapor akan diassesmen dan dinyatakan sebagai pecandu, status kriminalnya berubah menjadi tidak dituntut pidana, tujuan rehabilitasi adalah menyembuhkan kondisi sakit ketergantungan narkotika terhadap para penyalah guna dan pecandu agar pulih dari penyakit adiksi/ketergantungan narkotika.

Berdasarkan uraian di atas, dapat dilihat bahwa masih terjadi tumpang tindih dan ketidaksesuaian antar regulasi yang satu dengan yang lainnya, serta antara regulasi dengan

${ }^{22}$ Ibid.

${ }^{23}$ Anang Iskandar, Berita Harian Online (14 Januari 2019), Dalil Penyalahguna Narkoba, Rehabilitasi = Hukuman Penjara?, https://surabaya.tribunnews.com/2019/01/14/dalil-penyalahguna-narkoba-rehabilitasihukuman-penjara. 
implementasinya. Misalnya, pada Pasal 54 menyatakan, pecandu narkotika dan korban penyalahgunaan narkotika wajib menjalani rehabilitasi medis dan rehabilitasi sosial. Sementara Pasal 127 memerintahkan, setiap penyalahguna narkotik golongan I hingga III dipidana penjara. Kontradiksi antar pasal dalam satu payung regulasi yang sama jelas menimbulkan kebingungan khususnya bagi masyarakat awam, terlebih lagi dikhawatirkan hal ini menimbulakn keraguan bagi aparat penegak hukum dalam memberikan vonis, menciptakan keadilan dan mewujudkan kepastian hukum. Karena sejatinya diharapkan penjatuhan vonis terkait pelaku-pelaku tindak pidana narkotika ini, tidak hanya memberi efek jera dan selesai sebatas mendekap di balik jeruji besi, namun output setelah terdakwa kembali ke masyarakatlah yang diharapkan dapat menjadi pribadi taat hukum tanpa ada kemungkinan untuk mengulang kembali tindak pidanya yang telah ia lakukan sebelumnya

\section{Kesimpulan}

1. Kebijakan kiminal pencegahan dan penanggulangan narkotika di Indonesia dilakukan dengan 2 (dua ) cara yaitu kebijakan Penal dan Non penal. Aspek Penal, diawali dengan analisis terhadap ketentuan perundang-undangan pidana yang berkaitan dengan narkotika dan psikotropika khususnya terhadap kebijakan hukum pidana (penal policy), melalui kajian normatif yang merupakan tahap kebijakan legislatief. Kajian selanjutnya dilakukan dengan mengamati pelaksanaan ketentuan perundang-undangan pidana (in abstrakto) narkotika dan psikotropika ke perundang-undangan pidana (in konkrito) melalui mekanisme sistem peradilan pidana terpadu yang merupakan tahap kebijakan aplikatief yang selanjutnya akan diteruskan pada tahak kebijakan eksekutif. Temuan dari analisis hasil penelitian aspek penal terhadap narkotika dan psikotropika, merupakan bahan masukan untuk melakukan perbaikan dalam perencanaan penanggulangan penyalahgunaan narkotika dikemudian hari.Aspek Non Penal (pencegahan)merupakan aspek yang sangat strategisoleh karena tindak pidana (kejahatan) belum terjadi. Selain melakukan peneropongan apa yang telah dilakukan oleh aparat penegak hukum dalam melakukan pencegahan terhadap penyalahgunaan narkotika selama ini, juga kajian perencanaan ini akan menawarkan alternatif non penal lain sehubungan dengan penyalahgunaan narkotika.

2. Selain dengan peraturan perundang-undangan upaya penanggulangan dan pecegahan Narkotika dilakukan secara sinergi beberapa lembaga yang terkait satu sama lain ,P4GN adalah Pemberantasan Peredaran Gelap Narkoba dan Perkusor yang merupakan suatu 
program penanggulangan pencegahan narkotika. Pencegahan Pemberantasan Penyalahgunaan dan Peredaran Gelap Narkoba (P4GN) adalah upaya sistematis berdasarkan data penyalahgunaan narkoba yang tepat dan akurat, perencanaan yang efektif dan efisien dalam rangka mencegah, melindungi dan menyelamatkan warga negara dari ancaman bahaya penyalahgunaan narkoba untuk itu diperlukan kepedulian dari seluruh instansi pemerintah dalam upaya tersebut dengan mendorong satgas di instansi pemerintah menjadi pelaku P4GN secara mandiri. Upaya yang paling tepat dalam pencegahan dan penyalahgunaan narkotika adalah upaya demand yang menitik beratkan pada perbaikan pelaku yaitu penyuluhan dan juga rehabilitasi. Dibandingkan penjara , rehabilitasi lebih tepat dilaksanakan bagi pengguna narkotika. Dikarenakan efek negatif penjara yang belum tentu memperbaiki keadaan pelaku . Namun pada kenyataannya, hakim sangat jarang memutus dengan putusan rehabilitasi

\section{E. Rekomendasi}

1. Upaya yang paling tepat dalam pencegahan narkotika adalah dengan cara penyuluhan. Diharapkan kegiatan yang dilakukan oleh lembaga- lembaga terkait ditingkatkan lagi dan menggandeng pihak masyarakat agar penyuluhan lebih efektif

2. Selain penyuluhan terhadap masayarakat, diharapkan ada program penyuluhan terhadap penegak hukum tentang penanganan kasus-kasus narkotika.

3. Peran serta masyarakat guna pencegahan penyalagunaan narkotika dapat diwujutkan dalam bentuk-bentuk kegiatan yakni melakukan pengawasan terhadap semua aktivitas warga masyarakat agar tidak menyalahgunakan penggunaan narkotika yang illegal itu,kewajiban masyarakat untuk melapor kepada pihak yang berwenang bila mengetahui tentang narkoba yang disalahgunakan. Akan tetapi masyarakat harus diberikan jaminan perlindungan hukum dan keamanan oleh penegak hukum. Uraian tentang partisipasi masyarakat merupakan salah satu wujud nyata dalam sebuah Negara yang Demokratis.

4. Rehabilitasi bagi pengguna narkotika hendaknya lebih diutamakan daripada pidana penjara.

\section{F. Daftar Pustaka}

Agustinus Widdy., dkk. Indonesia Drugs Report 2019, Pusat Penelitian data dan Informasi BNN , Jakarta, 2019

Moh Taufik Makaro,et.al, Tindak Pidana Narkotika, Ghalia Indonesia, Bogor,2015 
Marc Ancel, Social Defence; A Modern Approach to Criminal Problem, Routledge and Kegan Paul, London, 1965

Sudarto, Kapita Selekta Hukum Pidana, PT Alumni, Bandung, 2006

Sudarto, Hukum dan Hukum Pidana, Alumni, Bandung, 1977

Theo Huijbers OSC, Filsafat Hukum Dalam Lintas Sejarah, Yayasan Kanisius, Bandung, 1982. 